\title{
The long term outcome of limbal allografts: the search for surviving cells
}

\author{
Timothy R M Henderson, Douglas J Coster, Keryn A Williams
}

\begin{abstract}
Backgroundlaims-Limbal allotransplantation is increasingly being used for ocular surface repair in patients with limbal stem cell dysfunction. However, it is uncertain whether donor cells survive long term on the ocular surface and whether patients maintain the early benefits of the procedure. The aims of this study were to investigate the long term outcome of clinical limbal allografts and to correlate outcome with donor cell survival.

Methods-Five patients who had undergone allotransplantation-four keratolimbal allografts and one tarsoconjunctival allograft-from 3-5 years previously, and for whom residual frozen donor ocular tissue was available, were reviewed. Survival of donor cells lifted from the recipient ocular surface by impression cytology was investigated by DNA fingerprinting using primers detecting variable nucleotide tandem repeat sequences. Recipient buccal cells and scleral samples from the remnant donor eye were used to genotype recipients and donors, respectively. Polymerase chain reaction products were sized by Genescan analysis.
\end{abstract}

Results-An objective long term benefit from the procedure (improved Snellen acuity, reduced frequency of epithelial defects, reduced vascularisation, and scarring) was recorded for four patients. Some subjective benefit was also reported. However, in no instances were donor cells recovered from the ocular surface at 3-5 years post-graft. Initial experiments to examine sensitivity indicated that any surviving donor cells must have constituted less than $2.5 \%$ of cells sampled.

Conclusion-Limbal stem cell allotransplantation can provide long term benefits, as measured by objective criteria. However, such benefits do not necessarily correlate with survival of measurable numbers of donor cells on the ocular surface. (Br F Ophthalmol 2001;85:604-609) K A Williams, $\mathrm{PhD}$ Department of Ophthalmology, Flinders University of South Australia, GPO Box 2100, Adelaide, SA 5001, Australia keryn.williams@ flinders.edu.au

Accepted for publication 18 December 2000 his colleagues ${ }^{4-7}$ demonstrated the value conjunctival and limbal transplantation for limbal stem cell dysfunction, clinical limbal allotransplantation has been embarked upon with some enthusiasm..$^{7-12}$ The use of corneal stem cell autografts is now well established in cases of unilateral stem cell deficiency. ${ }^{13}{ }^{14}$ Support for the efficacy of corneal stem cell allotransplantation remains more tenuous, but the procedure has been reported to result in stabilisation of the ocular surface in cases of bilateral disease, with reduction in symptoms at least in the short term, and early visual rehabilitation. ${ }^{10}{ }^{11}$ However, some recent studies have shown evidence for relatively limited survival of donor cells on the ocular surface ${ }^{15} 16$ The issue of whether adequate immunosuppression might significantly improve graft survival remains unresolved but has some support in both clinical $^{1117}$ and experimental studies. ${ }^{18-20}$ The purpose of this study was to investigate the long term outcome of limbal stem cell transplantation and to correlate graft outcome with donor cell survival on the ocular surface.

\section{Materials and methods}

PATIENTS

A heterogeneous group of five patients who had undergone limbal or tarsoconjunctival allotransplantation between 3 and 5 years previously and for whom residual donor eye tissue had been frozen at $-20^{\circ} \mathrm{C}$ was identified. The details of patient presentation, indications for surgery, operative procedure performed, duration of follow up and the immunosuppression administered postoperatively are shown in Table 1. Patient D formed the subject of an earlier report in which follow up extended for 20 weeks postoperatively. ${ }^{15}$ Patients were reviewed in the clinic by an ophthalmologist not otherwise connected with the care of these individuals and all grafted eyes were photographed. Each patient was questioned as to whether he or she had experienced subjective benefit from the procedure. This study was undertaken with institutional approval and the informed consent of all patients involved.

EXTRACTION OF GENOMIC DNA FROM BUCCAL CELLS, SCLERA, CORNEAL EPITHELIAL CELLS, AND PERIPHERAL BLOOD LYMPHOCYTES

Buccal cells and scleral samples from the remnant donor eye were used to genotype recipients and donors, respectively. Buccal cells were obtained by a brief mouthwash with sterile water. Cells from $1 \mathrm{ml}$ of mouthwash sample were pelleted 1 minute at $4000 \mathrm{~g}$. 
Table 1 Details of patients, presenting diseases, procedure performed, duration of follow up, and immunosuppression

\begin{tabular}{|c|c|c|c|c|}
\hline $\begin{array}{l}\text { Patient age at } \\
\text { graft (years), sex }\end{array}$ & Indication for limbal allograft & Procedure & $\begin{array}{l}\text { Duration follow } \\
\text { up (months) }\end{array}$ & Immunosuppression, duration treatment \\
\hline (A) $50, \mathrm{M}$ & Epithelial dysplasia affecting both eyes and skin & $\mathrm{R} 360^{\circ}$ limbal allograft & 36 & prednisolone phosphate $0.5 \%$ qds, 4 months \\
\hline (B) $34, \mathrm{~F}$ & $\begin{array}{l}\text { Aniridic keratopathy, worse in right eye } \\
\text { (primary limbal failure) }\end{array}$ & $\mathrm{R} 360^{\circ}$ limbal allograft & 45 & prednisolone phosphate $0.5 \%$ qds, 13 months \\
\hline (C) $71, \mathrm{M}$ & $\begin{array}{l}\text { Limbal carcinoma in situ, biopsy proved } \\
\text { recurrence, previous limbal graft failure }\end{array}$ & $\begin{array}{l}\mathrm{R} 360^{\circ} \text { limbal allograft; corneal } \\
\text { surface replaced }\end{array}$ & 54 & $\begin{array}{l}\text { prednisolone phosphate } 0.5 \% \text { qds, } 4 \text { months } \\
\text { prednisolone phosphate } 0.5 \% \text { bd, } 50 \text { months }\end{array}$ \\
\hline (D) $47, \mathrm{~F}$ & Contact lens induced limbal failure & $\mathrm{R}$ limbal allograft $2 \times 3$ clock hours & 56 & $\begin{array}{l}\text { prednisolone phosphate } 0.5 \% \text { qds, } 28 \text { months } \\
\text { cyclosporin } 200-100 \mathrm{mg} \text { bd, } 56 \text { months } \\
\text { azathioprine } 100-25 \mathrm{mg} \mathrm{od}, 15 \text { months }\end{array}$ \\
\hline (E) $67, \mathrm{M}$ & $\begin{array}{l}\text { Subtarsal well differentiated squamous cell } \\
\text { carcinoma with invasive foci }\end{array}$ & $\begin{array}{l}\text { L upper lid tarsoconjunctival } \\
\text { allograft; corneal surface replaced }\end{array}$ & 56 & $\begin{array}{l}\text { prednisolone phosphate } 0.5 \% \text { qds, } 1 \text { week } \\
\text { prednisolone phosphate } 0.5 \% \text { tds, } 11 \text { months } \\
\text { mitomycin C } 0.02 \% \text { od, alternate weeks }\end{array}$ \\
\hline
\end{tabular}

qds = four times daily; bd = twice daily; od = once daily; tds = three times daily.

Genomic DNA was extracted by incubating the cells at $60^{\circ} \mathrm{C}$ for 2 hours in $25 \mu$ of extraction buffer containing $60 \mu \mathrm{g} / \mathrm{ml}$ proteinase $\mathrm{K}$, followed by 15 minutes of incubation at $95^{\circ} \mathrm{C} . .^{15}$ Frozen remnant donor eyes were partially thawed to allow a $3 \times 5 \mathrm{~mm}$ fragment of sclera to be dissected. In the case of patient C who had undergone two graft procedures from two different donors, remnants of both donor eyes were available. Scleral fragments were pulverised in a sterile metal mortar and pestle, precooled with liquid nitrogen. The resulting powder was transferred to sterile eppendorf tubes and genomic DNA extracted in $200 \mu \mathrm{l}$ of FTA buffer (Fitzco Inc, Maple Plain, MN, USA) according to the manufacturer's recommendations. Corneal epithelial cells from the ocular surface of patients with limbal allografts were harvested by impression cytology using $6 \mathrm{~mm}$ discs of FTA paper and processed according to the manufacturer's recommendations. Impression cytology was performed on both the central and peripheral cornea of each grafted eye. Venous peripheral blood was collected from two healthy volunteers into heparinised tubes. Peripheral blood lymphocytes (PBL) were purified over FicollHypaque gradients, washed in sterile $0.9 \%$ saline, and resuspended to $1.5 \times 10^{6} \mathrm{cells} / \mathrm{ml}$. DNA was extracted in the same manner as for buccal cells.

DNA FINGERPRINT ANALYSIS

All analyses were performed on at least two occasions. FTA paper discs were cut with a sterile blade into $1 \times 2 \mathrm{~mm}$ fragments and a single fragment used in each reaction. Four forensic forward and reverse primers labelled with fluorescent dyes were provided by Dr F Firgaira (Department of Haematology, Flinders Medical Centre, Adelaide, Australia). D165393-hex and D165498-fam detected dinucleotide repeats of allele size $130-158$ base pairs (bp) and 208-246 bp, respectively.
D165539-fam and vWF-1-fam detected tetranucleotide repeat sequences of allele size 148-172 bp and 150-180 bp, respectively. Optimised polymerase chain reaction (PCR) mixtures were: $1.2 \mu \mathrm{l} 25 \mathrm{mM} \mathrm{MgCl}_{2}, 1.0 \mu \mathrm{l} 4$ mM dNTPs, $2.0 \mu 1$ 10x buffer, $0.2 \mu \mathrm{l} 1.0 \mathrm{U}$ Taq-gold polymerase (all from Perkin Elmer Roche Molecular Systems, Branchburg, NJ, USA), $1.0 \mu 1100 \mathrm{ng} / \mu \mathrm{l}$ forward primer, $1.0 \mu \mathrm{l}$ $100 \mathrm{ng} / \mu \mathrm{l}$ reverse primer, 8.6 $\mu \mathrm{l}$ water. Thermocycler conditions were: one cycle at $95^{\circ} \mathrm{C}$ for 10 minutes; 10 cycles at $94^{\circ} \mathrm{C}$ for 30 seconds, $60^{\circ} \mathrm{C}$ for 30 seconds, and $72^{\circ} \mathrm{C}$ for 1 minute; 35 cycles at $94^{\circ} \mathrm{C}$ for 30 seconds; $55^{\circ} \mathrm{C}$ for 30 seconds and $72^{\circ} \mathrm{C}$ for 1 minute, final cycle at $72^{\circ} \mathrm{C}$ for 10 minutes and $35^{\circ} \mathrm{C}$ for 10 seconds. PCR products were visualised on ethidium bromide agarose gels before being sized on an automated DNA sequencer that used Genescan software (Applied Biosystems Inc, La Jolla, CA, USA).

\section{SENSITIVITY OF DETECTION OF PCR}

The sensitivity of detection of the PCR was established in preliminary experiments using known concentrations of PBL. Firstly, 10-fold dilutions of PBL from a single donor in Dulbecco's A phosphate buffered saline (PBS) were prepared and the DNA extracted. Secondly, two reciprocal dilution series in which cells from one PBL donor were diluted with cells from the other donor were set up and similarly extracted. Initial experiments showed that $30-40$ cells in a sample of PBL from a single donor could reliably be fingerprinted, whereas no adequate Genescan product peaks could be detected in samples containing three to four cells (data not shown). Dilution series using PBL from two different individuals indicated that it was possible to identify the minority cell type in a mixed cell sample when it constituted $2.5 \%$ or more of the sample (data not shown).

Table 2 Clinical outcomes after limbal or tarsoconjunctival allotransplantation

\begin{tabular}{|c|c|c|c|c|c|}
\hline Patient & $\begin{array}{l}\text { Preoperative acuity } \\
\text { (with } \mathrm{PH} \text { ) }\end{array}$ & $\begin{array}{l}\text { Best postoperative } \\
\text { acuity (with PH) }\end{array}$ & $\begin{array}{l}\text { Long term } \\
\text { acuity }\end{array}$ & $\begin{array}{l}\text { Subjective } \\
\text { benefit }\end{array}$ & Objective benefit \\
\hline A & $\mathrm{HM}$ & HM & $\mathrm{HM}$ & Yes & Reduced frequency of epithelial defects \\
\hline B & $\mathrm{CF}$ & $\mathrm{CF}$ & $\mathrm{CF}$ & Yes & None \\
\hline C & $6 / 36$ & $6 / 18$ & $6 / 24$ & Yes & $\begin{array}{l}\text { Reduced vascularisation, stromal scarring, and } \\
\text { epithelial defects. No recurrence of limbal carcinoma } \\
\text { in situ but corneal surface is keratinised }\end{array}$ \\
\hline D & $6 / 60(6 / 9)$ & $6 / 12(6 / 9)$ & $6 / 18$ & Yes & Reduced degree of stromal scarring \\
\hline $\mathrm{E}$ & $6 / 36(6 / 18)$ & $6 / 18$ & $\mathrm{CF}$ & No & $\begin{array}{l}\text { No recurrence of carcinoma; ocular surface is } \\
\text { completely keratinised }\end{array}$ \\
\hline
\end{tabular}

$\mathrm{PH}=$ pinhole, $\mathrm{HM}=$ hand movements, $\mathrm{CF}=$ counting fingers at 1 metre. 


\section{Results}

CLINICAL OUTCOME OF LIMBAL

ALLOTRANSPLANTATION

The clinical outcome for each patient at 3-5 years after limbal allotransplantation is summarised in Table 2. A long term improvement in Snellen acuity without pinhole was recorded
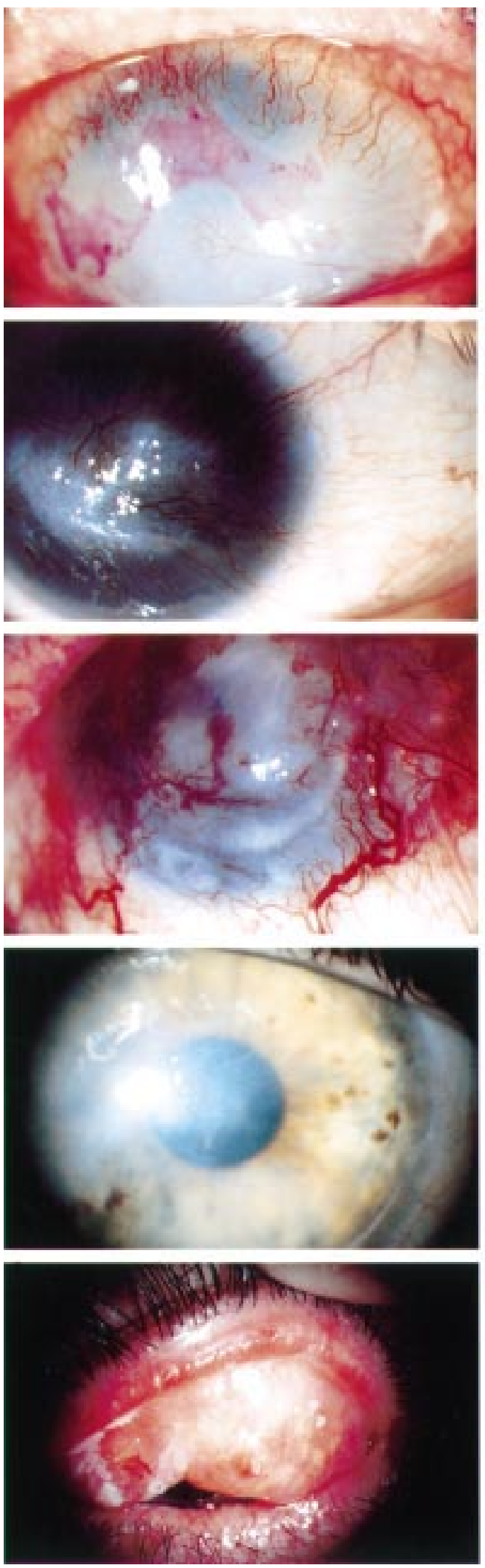

for two patients and other objective benefit was apparent for four patients. All patients reported that they would undergo the same procedure again, even with the benefit of hindsight. With the exception of patient $\mathrm{E}$ who had received a tarsoconjunctival allograft for carcinoma in situ, all patients considered that the procedure
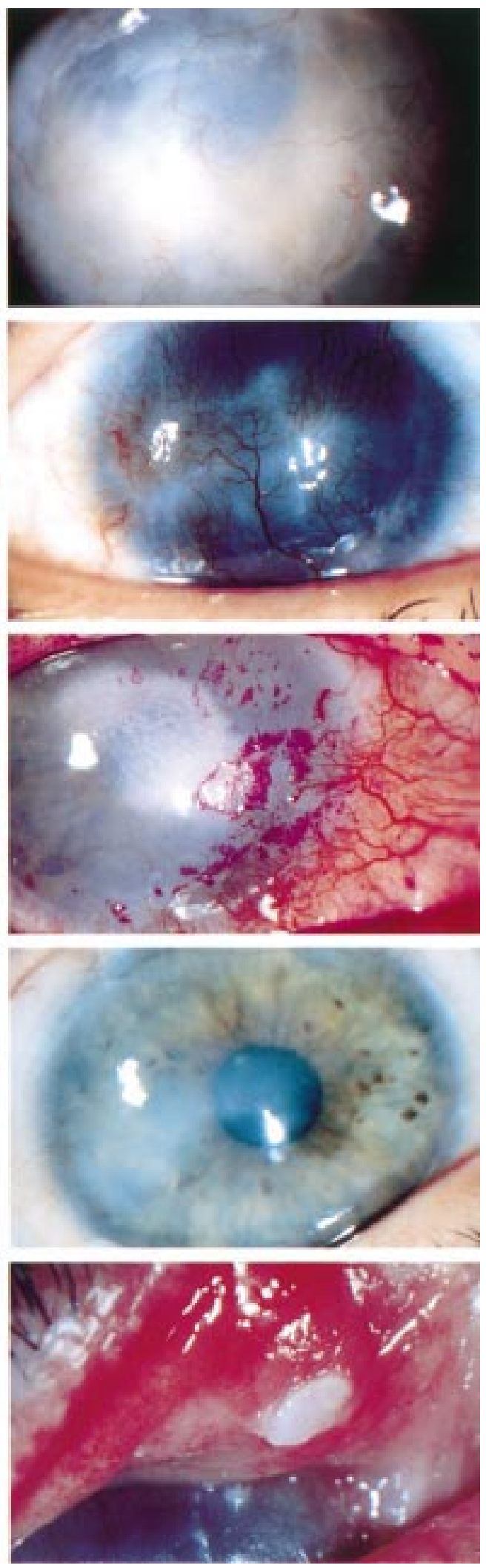

Figure 1 Clinical photographs of operated eyes showing the

appearance immediately preceding surgery on the left hand side and the

appearance of the same eye at the study review
right hand side. 
Table 3 DNA fingerprint analyses - all numbers refer to Genescan peak positions in base pairs

\begin{tabular}{|c|c|c|c|c|c|c|c|c|c|c|}
\hline \multirow{3}{*}{$\frac{\text { Patient }}{\text { (A) }}$} & \multirow{3}{*}{$\begin{array}{l}\text { Sample } \\
\text { Recipient }\end{array}$} & & & \multicolumn{6}{|c|}{ Microsatellite primer: } & \multirow{3}{*}{$\begin{array}{l}\text { Evidence for } \\
\text { donor cell } \\
\text { survival? }\end{array}$} \\
\hline & & \multicolumn{2}{|c|}{ D165393 } & \multicolumn{2}{|c|}{ D165498 } & \multicolumn{2}{|c|}{ D165539 } & \multicolumn{2}{|c|}{$v W F-1$} & \\
\hline & & 145 & 155 & 219 & 245 & 151 & 159 & 164 & 168 & \\
\hline & Donor & 141 & 154 & 209 & - & 151 & 163 & 158 & 164 & \\
\hline & $\begin{array}{l}\text { Ocular } \\
\text { surface }\end{array}$ & 141 & 154 & 219 & 245 & 150 & 158 & 164 & 168 & No \\
\hline \multirow[t]{3}{*}{ (B) } & Recipient & 141 & 151 & 218 & 245 & 163 & 167 & 168 & 176 & \\
\hline & Donor & 135 & 148 & 219 & 223 & 151 & 167 & 168 & 176 & \\
\hline & $\begin{array}{l}\text { Ocular } \\
\text { surface }\end{array}$ & 142 & 152 & 219 & 245 & 163 & 167 & 168 & 176 & No \\
\hline \multirow[t]{4}{*}{ (C) } & Recipient & 142 & 148 & - & 245 & 155 & 175 & 168 & 176 & \\
\hline & Donor 1 & 141 & 153 & 220 & 245 & 158 & 162 & 164 & - & \\
\hline & Donor 2 & 143 & 156 & 218 & - & 159 & 167 & 164 & 168 & \\
\hline & $\begin{array}{l}\text { Ocular } \\
\text { surface }\end{array}$ & 142 & 148 & - & 245 & 154 & 174 & 168 & 176 & No \\
\hline \multirow[t]{3}{*}{ (D) } & Recipient & 141 & - & 218 & 223 & 151 & 159 & 164 & 168 & \\
\hline & Donor & 135 & 148 & 219 & 223 & 151 & 167 & 168 & 176 & \\
\hline & $\begin{array}{l}\text { Ocular } \\
\text { surface }\end{array}$ & 141 & - & 219 & 223 & 150 & 158 & 164 & 168 & No \\
\hline \multirow[t]{3}{*}{ (E) } & Recipient & 146 & 150 & 219 & - & - & 166 & - & 168 & \\
\hline & Donor & 141 & 155 & 209 & 219 & 151 & 163 & 164 & 168 & \\
\hline & Tarsal surface & 146 & 150 & 219 & 245 & 156 & 167 & 160 & 168 & No \\
\hline
\end{tabular}

Figures in bold type indicate discriminatory alleles which, had they been found in the ocular surface sample, would have indicated persistence of donor cells.

$-=$ absence of a second allele, usually resulting from homozygosity at that locus but rarely resulting from preferential amplification or failure of amplification during PCR.

had helped them. Ocular surface comfort improved for patients A, C, and D. Functional capability improved with benefit to peripheral vision (patient $\mathrm{C}$ ), ability to drive a car (patient D), and ease of reading (patient B). Figure 1 shows the preoperative appearance of the grafted eye for each patient, together with the appearance at the most recent follow up.

DNA FINGERPRINTING OF RECIPIENTS, DONORS, AND GRAFTED EYES

DNA fingerprints were obtained from all samples tested, and no difference was found in samples obtained from the central or peripheral cornea of any patient. A representative Genescan trace obtained for patient $\mathrm{C}$ is shown in Figure 2. The DNA fingerprint analyses for each recipient, donor, and for cells harvested from eyes bearing limbal allografts are shown in Table 3. With the exception of a single buccal cell sample from patient E, primers detecting alleles at each of the microsatellite loci gave clear peaks within the correct product size range, and individuals were clearly heterozygous or homozygous at each locus. For patient E, an anomalous peak not corresponding to either the donor or the recipient buccal sample was obtained in DNA harvested from the tarsal surface, but overall, sufficient product peaks were present to show that the tarsal conjunctival sample matched the buccal cell sample. One allele detected at one locus in patient A matched that of the donor and the finding was consistent upon repeat scanning. However, the absence of any other discriminatory peaks from the donor suggested that significant donor cell survival had not occurred. In summary, no unequivocal evidence for survival of donor derived cells on the ocular surface of the grafted eyes was obtained for any of the five patients.

\section{Discussion}

The transplantation of populations of ocular epithelial stem cells from donor eyes has become an established surgical treatment for severe ocular surface disease secondary to stem cell dysfunction. The short term benefits of such procedures to the recipient are often plain. However, long term benefits remain somewhat uncertain, possibly because grafts of histoincompatible tissue do not survive after transplantation. Certainly, immunosuppression is usually administered to recipients of limbal allografts with the explicit goal of preventing allograft rejection. We examined five patients at 3-5 years after limbal allotransplantation in order to correlate long term outcomes with survival of donor cells on the ocular surface. This study differs from those we have reported previously ${ }^{1015} 16$ in several key aspects. Firstly, multiple microsatellite markers were used to improve the chances of detecting surviving donor cells on the ocular surface. Secondly, the patients in this study had been followed for at least 3 years after surgery, by which time we could be reasonably certain that outcomes were relatively stable. We were thus in a position to determine long term benefits, if any, to the recipients.

In spite of the disparate indications for allografting in our patients, the long term outcome for the group as a whole was one of qualified improvement, with some stabilisation of the ocular surface after 3-5 years of follow up. Interestingly, the subjective benefit was disproportionately greater than the objective findings would have suggested, particularly given that we were unable to show significant levels of surviving donor cells on the ocular surface of the grafted eye in any of the patients investigated.

Microsatellite markers ${ }^{21}$ were used to identify the genotype of cells lifted from the ocular surface by impression cytology. Of the four variable nucleotide tandem repeat loci examined, two were dinucleotide repeats and two were tetranucleotide repeats. The Genescan product peaks obtained with the latter were better defined with fewer stutter bands than were the former. A degree of preferential amplification of product occurred during PCR with the dinucleotide repeat primers but was insufficient to affect resolution. Any Genescan product peak differing by more than two base pairs may be utilised as a clearly discriminatory peak, and the greater the number of markers used, the smaller the chance that any two individuals will be identical at all loci examined. In the five patients examined in this study, all four markers were discriminatory between donor and recipient in three instances, and three of four were discriminatory in the remaining two instances.

The nature of PCR is such that amplification of a more prevalent sequence is favoured at the expense of a minority sequence. In a mixed cell population such as is at least theoretically represented by the grafted ocular surface, the limit of detection of the minority species might be higher than otherwise expected. Preliminary experiments suggested that a minority cell population would be detectable only if it constituted $2.5 \%$ or more of the sample. It follows that should any donor cells be surviving 

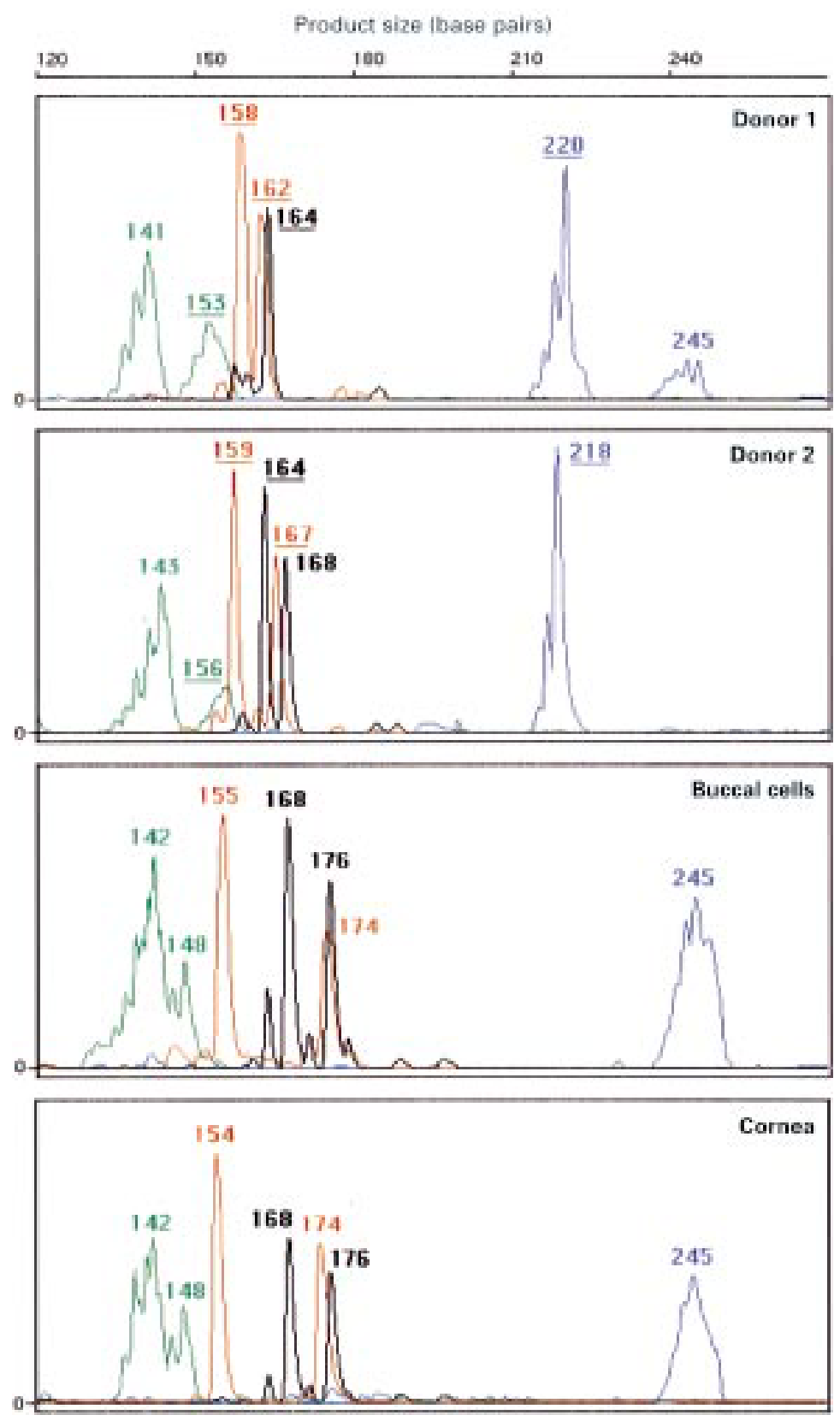

Figure 2 Series of DNA fingerprints obtained from ocular surface (cornea) and buccal samples in patient $C$ and the fingerprints from stored donor material. The peaks for each primer are shown in a different colour and correspond to the values in Table 3.

on the ocular surface of our patients, those cells must constitute less than $2.5 \%$ of the population of cells sampled by impression cytology. Sampling achieved by impression cytology may be patchy, but generally the superficial two to three layers of the epithelial surface are lifted off with the impression. ${ }^{22}$ It is possible that some donor derived stem cells or transient amplifying daughter cells might persist in the basal epithelium and thus not be sampled. However, it should be noted that two of the patients described in this study underwent procedures in which essentially the entire ocular surface was replaced with donor tissue.

If very low levels of donor stem cells persist long term or if such cells do not persist at all, it is interesting to speculate how limbal allotransplantation might stabilise the ocular surface.
Possibly the graft matrix improves the local environment for residual host stem cells, which are then enabled to repopulate the ocular surface sufficiently to allow the patient to perceive an improvement. Perhaps grafted cells enhance the stem cell "niche" by provision of growth factors or soluble mediators. The actual surgical procedure and subsequent healing response may help to reduce neovascularisation and scarring at least in the short term, especially if superficial keratectomy has been performed. It is not yet known to what extent immunosuppression can prevent or delay the decline in numbers of donor cells that plainly occurs with time. It is, however, clear that donor stem cells do not necessarily stabilise the ocular surface by substantial repopulation of the epithelium as originally envisaged. The one recipient in our series (patient D) who remained on oral cyclosporin for almost 5 years showed no evidence of donor cell survival on the ocular surface. However, it proved difficult to wean her off systemic cyclosporin despite side effects including hirsutism and voice changes. Ocular discomfort and significant conjunctival and limbal hyperaemia recurred whenever attempts were made to taper the cyclosporin dosage. It seems likely that an underlying dysplasia may have been kept in remission by the immunosuppression.

In conclusion, this study suggests that the assumption that stabilisation of the ocular surface after limbal allotransplantation is correlated with significant levels of donor cell survival may not be merited. Stabilisation does occur, although early improvement may regress after some months. Some objective and subjective benefits to the recipient may be apparent in the absence of detectable levels of donor cell survival on the ocular surface. Persisting subjective improvement may represent a placebo effect, at least in part, but may also reflect a hitherto unrecognised biological effect of the transplantation procedure. The value to the patient should not be underestimated, but the risks associated with prolonged, systemic immunosuppression may not be justified.

This work was supported by the Australian National Health and Medical Research Council and the Ophthalmic Research Institute of Australia. The authors thank Mrs Susan Harris and Dr Frank Figaira for invaluable assistance. TRMH was supported by the Sir William Lister Award, the Ethicon Travel Award, and by the Sir William Lister Award, the Ethicon Trave
the Leeds Teaching Hospitals' Special Trustees.

1 Kinoshita S, Kiorpes TC, Friend J, et al. Limbal epithelium in ocular surface wound healing. Invest Ophthalmol Vis Sci

2 Thoft RA, Wiley LA, Sundarraj N. The multipotential cells of the limbus. Eye 1989;3:109-13.

3 Turgeon PW, Nauheim RC, Roat MI, et al. Indications for keratoepithelioplasty. Arch Ophthalmol 1990;108:233-6.

4 Kenyon KR, Tseng SCG. Limbal autograft transplantation for ocular surface disorders. Ophthalmology 1989;96:70923.

5 Tsai RJF, Sun TT, Tseng SCG. Comparison of limbal and conjunctival autograft transplantation in corneal surface reconstruction in rabbits. Ophthalmology 1990;97:446-55.

6 Tsai RJ-F, Tseng SCG. Human allograft limbal transplantation for corneal surface reconstruction. Cornea 1994;13: 389-400.

7 Tseng SC, Prabhasawat P, Barton K, et al. Amniotic membrane transplantation with or without limbal allografts for corneal surface reconstruction in patients with limbal stem corneal surface reconstruction in patients with limbal

8 Jenkins C, Tuft S, Liu C, et al. Limbal transplantation in the management of chronic contact lens associated epithelio-
maten pathy. Eye 1993;7:629-33. 
9 Pfister RP. Corneal stem cell disese: concepts, categorisation, and treatment by auto- and homotransplantation of tion, and treatment by auto- and homotran

10 Coster DJ, Aggarwal RK, Williams KA. Surgical management of ocular surface disorders using conjunctival and stem cell allografts. Br F Ophthalmol 1995;79:977-982

11 Tan DTH, Ficker LA, Buckley RJ. Limbal transplantation. Ophthalmology 1996;103:29-36.

12 Holland EJ, Schwartz GS. The evolution of epithelial transplantation for severe ocular surface disease and a proposed classification system. Cornea 1996;15:549-56.

13 Copeland RA, Char DH. Limbal autograft reconstruction after conjunctival squamous cell carcinoma. Am f Ophthal mol 1990;110:412-15.

14 Herman WK, Doughman DJ, Lindstrom RL. Conjunctival autograft transplantation for unilateral ocular surface diseases. Ophthalmology 1983;90:1121-6.

15 Williams KA, Brereton H, Aggarwal R, et al. Use of DNA polymorphisms and the polymerase chain reaction to polymorphisms and the polymerase chain reaction to
examine the survival of human limbal stem cell allograft. Am 7 Ophthalmol 1995;120:342-50.
16 Henderson TRM, McCall SH, Taylor GR, et al. Do transplanted corneal limbal stem cells survive in vivo long-
term? Possible techniques to detect donor cell survival by polymerase chain reaction with the amelogenin gene and Y polymerase chain reaction with the am

17 Tsubota K, Toda I, Saito HS, et al. Reconstruction of the corneal epithelium by limbal allograft transplantation for severe ocular surface disorders. Ophthalmology 1995;102:1486-96.

18 Swift GJ, Aggarwal RK, Davis GJ, et al. Survival of rabbit limbal stem cell allografts. Transplantation 1996;62:568-74.

19 Shimazaki J, Kaido M, Shinozaki N, et al. Evidence of longterm survival of donor-derived cells after limbal allograft transplantation. Invest Ophthalmol Vis Sci 1999;40:1664-8.

$20 \mathrm{Xu} \mathrm{KP}$, Wu Y, Zhou J, et al. Survival of rabbit limbal stem cell allografts after administration of cyclosporin A. Cornea 1999;18:459-65.

21 Jeffreys AJ, Wilson V, Thein SL. Individual-specific 'fingerprints' of human DNA. Nature 1985;316:76-9.

22 Dart J. Editorial. Impression cytology of the ocular surface-research tool or routine clinical investigation? Brf Ophthalmol 1997;81:930.

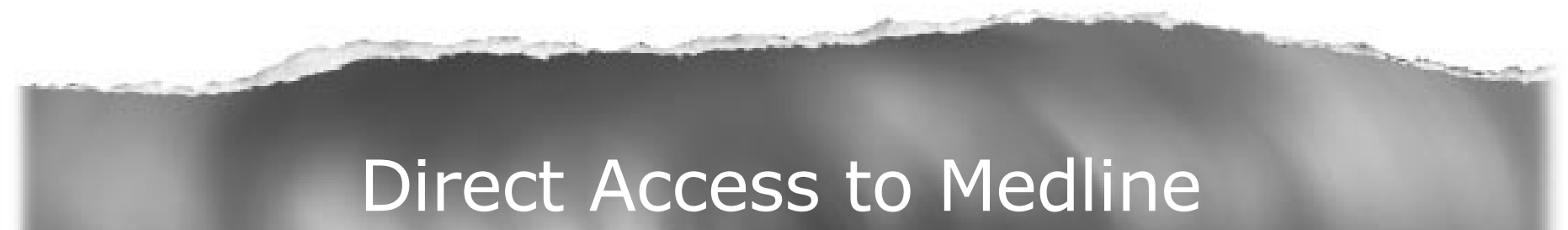

Medline

Link to Medline from the homepage and get straight into the National Library of Medicine's premier bibliographic database. Medline allows you to search across 9 million records of bibliographic citations and author abstracts from approximately 3,900 current biomedical journals.

www.bjophthalmol.com 